\title{
The Effectiveness of Plagiarism Checker Implementation in Scientific Writing for Vocational High School
}

\author{
Hakkun Elmunsyah, Hary Suswanto, Khoirudin Asfani, Wahyu Nur Hidayat \\ Electrical Engineering Department, Engineering Faculty \\ Universitas Negeri Malang \\ Malang, Indonesia \\ hakkun@um.ac.id
}

\begin{abstract}
The development of information technology today has negative impacts for education. These negative effects, among others, that hamper the quality of education are soft skill, especially honesty and self-confidence in their own work and copyright awareness. There are numerous plagiarism cases in Indonesia. Observations from various media and plagiarism interviews are not only done by students, but also teachers, and professors. Conceptually and procedurally, this development study used ADDIE model (Analysis, Design, Developed, Implement, and Evaluate). The population of this study was students of Vocational High School (VHS) in Malang. The qualitative data came from suggestions, criticisms, and general opinions of validators. While the quantitative data obtained from the data in the form of percentage and average score generated from the criteria in the questionnaire of media experts, material experts, and students. Based on the overall analysis of the data collection results, results obtained from Plagiarism Checker software showed very feasible. Another result of software experts was 91.67\% (which had the criteria categorized very feasible to use), small group $\mathbf{9 1 . 1 7 \%}$ (very suitable to use), a large group $\mathbf{9 0 . 3 9 \%}$ (very feasible to use). Plagiarism Checker software is very worthy used to test the similarity of scientific papers, because the results obtained above $85 \%$.
\end{abstract}

Keywords—softskill, plagiarism checkers, VHS, ADDIE.

\section{INTRODUCTION}

The role of education is to build good national characters. In fact, a good education system will more enhance the quality of education, where the quality of education can be assessed from the quality of graduates or the human resources in general. Therefore, qualified human resources become one of the important capital for the development progress of a country. It is highly relevant to [1] statement, that the management and development of natural resources must use Science and Technology (Science and Technology). Science and technology as one of development capital can only be used if its human resource have a good quality.

The results of research on the role of technology in many ways [2] revealed that information is not only a source of knowledge but also a special resource that can promote education, economic freedom, social, politic, and culture. It can be said that access and utilization of information and communication are the basics for development because it gives impact to every dimension of life. Likewise, information and communication poverty is one dimension of poverty that impacts on all other dimensions. For that reason, poverty reduction efforts of information and communication are interdependent with other dimensions.

Researchers are intrigued to overcome the rampant plagiarism in the world of education, especially for vocational education in order to contribute to the quality of the graduates including professionalism, independence and honest attitude. The government program named NAWACITA puts vocational education as the top priority of educational development. [3] This is realized with Jokowi Presidential Instruction No. 9 Year 2016 on the revitalization of vocational high school in order to improve the quality and competitiveness of Indonesian human resources, of which becoming the direction of vocational education development in future. [4] In addition to the Renstra State University of Malang 2015-2019, in the field of social, art, and culture, research is needed to care the improvement of national character building.

Preliminary study results at some vocational high schools in Malang city, known as the work task. It is a part of scientific work that is assessed among students that are categorized high similarity in one class or between classes. The rise of plagiarism cases of scientific work in the academic environment needs to be pursued by a solution so that the culture of appreciating the copyright of works can be continuously improved. The plagiarism background according to [5] provides a more concrete explanation. For instance, plagiarism occurs mostly because of some rationales including (a) not knowing what is meant by quotes and paraphrases and how to quote correctly, (b) delaying the task until the last moment, (c) assuming that plagiarism is the quickest way to accomplish tasks, (d) being confident that others will not detect what it does, and (e) not having more times to do the task because of bad time management, the procrastination of work, the perfectionist and unexpected conditions.

Permendiknas No. 17 Yeaar 2010, in article 1, paragraph 1 states that plagiarism is the act of intentionally or unintentionally in obtaining or trying to obtain credit or value for a scientific work, by quoting part of the entire work or scientific work of others without the right and adequate source [6]. Based on the above findings, the researcher was inspired to contribute to reduce the plagiarism in the world of education, especially for vocational education in order to contribute to the flight of educational graduates having good 
professionalism, independence and honest attitude for the future nation.

Plagiarism detection software of scientific papers for vocational education is expected to provide solutions for the above existing problems. This is the solution so far, that the tendency of plagiarism detector has two types namely paid or free. Moreover, the results were slightly not accurate and slow processing.

\section{METHOD}

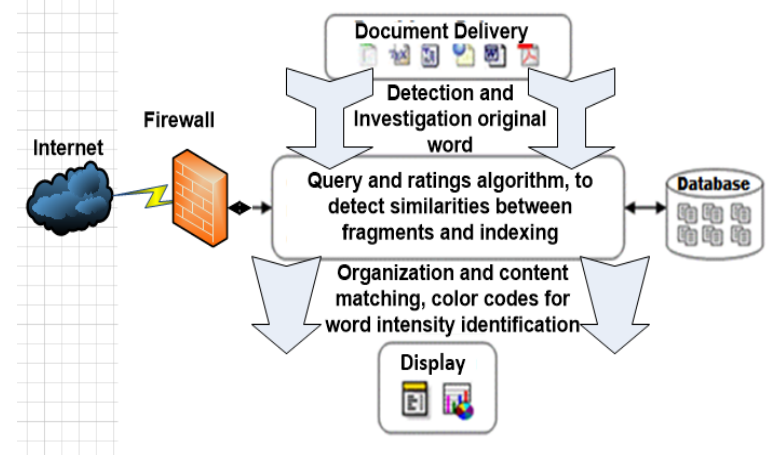

Fig. 1. Design model of "Plagiarism Checker Software"

In general the way the plagiarism detector software worked similarly in this study. The first stage of the offline model software received input data from the user, then the software started working by comparing the inputted file with the file created in comparison, then the last stage of the software presents the results. The difference in this model compared to current plagiarism detector software was using offline plagiarism detection model so that it required userselected comparative data itself (private server provision). In the next development would be added the choice of online services that had a wider and automatic comparison data that could also be accessed such as contained in Viper plagiarism detector software, Turn It In and so forth.

Plagiarism detector software resulted the output in the form of data presentation, if the data (in the form of papers) obtained words, sentences or paragraphs, then the software gave sign relevant to the features designed. The product research model was illustrated as Figure 1.

The development of this plagiarism detector software used ADDIE development model (Analysis, Design, Developed, Implement, Evaluate). The process of the ADDIE model development research procedure can be seen in Figure 2.

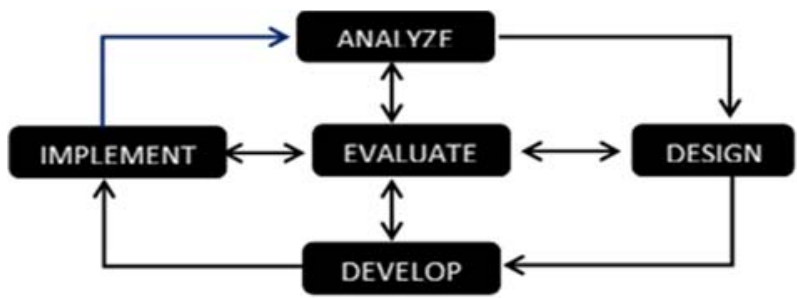

Fig. 2. ADDIE Development Research Model [7]
The total number of activities in the evaluation of plagiarism detector software development consisted 3 activities: (1) software evaluation from informatics system experts (2) small group evaluation conducted by 10 students of State VHS-2 Singosari Malang majoring on Software Engineering, and (3) field trials conducted by 36 students at State VHS-2 Singosari Malang, majoring on Software Engineering.

Types of the data from trials of plagiarism detector software products for students of class XI State VHS-2 Singosari Malang were qualitative and quantitative data. Qualitative data were derived from suggestions, criticisms and general opinions of validators. While the quantitative data were obtained from the data in the form of percentage and average score generated from the criteria in the questionnaire media experts, material experts, and students.

The data collection instrument used in this research and development was a questionnaire. After all the data collected then the next process that needed to be done was processing or analyzing to know the results of research and development that had been done. Processing or analyzing was done to know the product produced, feasible to use or not media that was said successful and according to criterion level if reaching score criterion $85 \%$. The collected data was then analyzed using qualitative descriptive analysis technique.

\section{RESULT AND DISCUSSION}

The developed device was a system of detection of similarity or plagiarism against scientific articles in class XI Software Engineering Skills Competence, SMK Negeri 2 Singosari Malang. This system helped analyze the similarity of scientific articles that would be uploaded with existing articles on the database installed on the local server host. In the process of analysis used Winnowing algorithm to simplify the system and to determine the similarity between scientific articles. Thus, it was known the percentage of originality of scholarly articles uploaded along with the location of similarities.

The winnowing algorithm was one of the algorithms used to detect the similarity between two or more texts. The method used in this algorithm was the fingerprint method [8]. The application of fingerprint used hash function to find similarity on a text or document. The selection of the minimum hash value in each window was a way of winnowing algorithm to detect text similarity [9].

Figure 3 is a scientific article detection page. This page displayed the form of scientific articles to upload. The information shown on this page included the title of the scientific article, the author, the year of publication, and a scientific article document in the form of a word document.

The form was filled in accordance with the terms. If not appropriate, it would be given a warning. The warning was part of the system validation, so the user entered the information as required (check mark $(\sqrt{ })$ appears on the side of the form). 


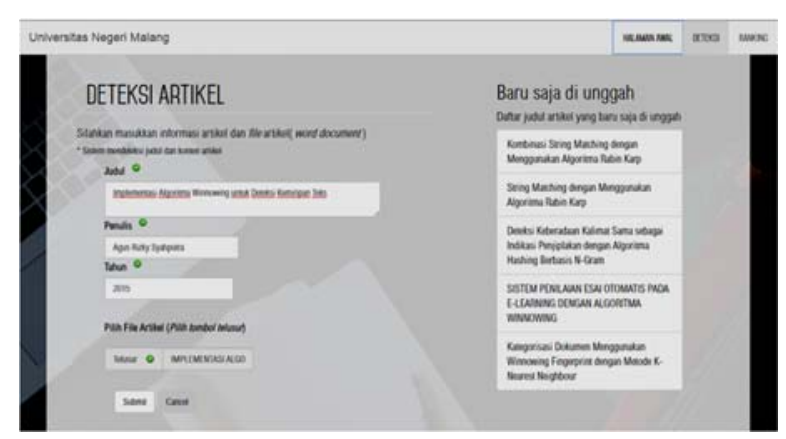

Fig. 3. Display detection form

History of scientific article detection results would be presented on the ranking page. The page rank displayed information about the percentage of scientific articles that had been detected previously. This page presented the similarity of articles detected from the highest percentage to the lower percentage. In the percentage box similarity was the percentage and title information of the two scientific articles compared. The display is shown in Figure 4.

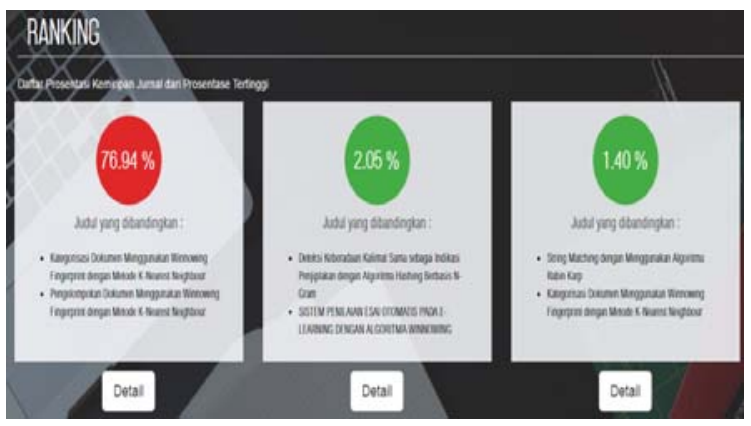

Fig. 4. Page rank

Following the presentation of the data validation software expert who is a professor of Electrical Engineering, State University of Malang. Data obtained from software expert validation results can be seen in Figure 5.

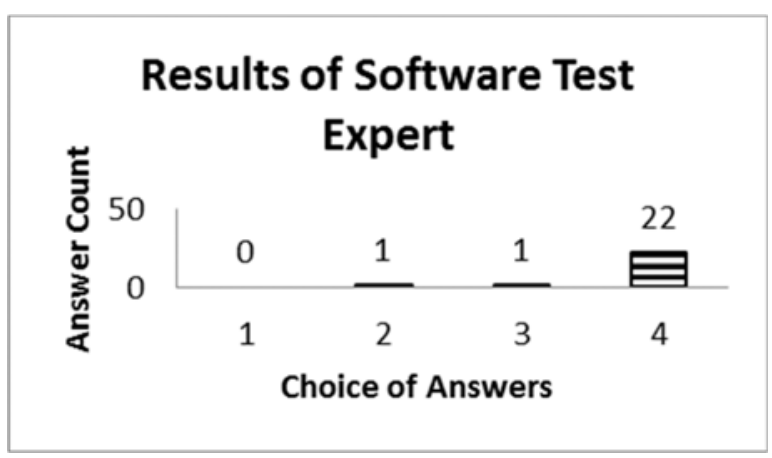

Fig. 5. Scores of Expert System Information Validation

Validation was obtained percentage for effectiveness and efficiency aspects in accordance with [10] about the criteria of validity and percentage analysis. Result showed very worth score obtained (TSe) from the media expert, that was 11. While the maximum score (TSh) was 12 . If calculated using the prescribed percentage formula, the result of media expert validation on the aspect of effectiveness and efficiency was (11: 12) x $100 \%=91.67 \%$ so this value fell within the worth criteria and according to what was delivered by [11] and [12] about the importance of a learning medium rather than the sophistication (let alone the expensive price). However, it must be rather onto the effectiveness and efficiency in helping the learning process. While the aspect of Audio and Video got $75.00 \%$ percentage and required a revision to perfect the media detector similarity of this scientific work.

TABLE I. RESULTS OF SOFTWARE EXPERT VALIDATION ANALYSIS

\begin{tabular}{|l|l|l|l|l|}
\hline NO & \multicolumn{1}{|c|}{ Indicators } & Tse & TSh & \multicolumn{1}{c|}{$\%$} \\
\hline 1 & Effectiveness \& Efficiency & 11 & 12 & $91.67 \%$ \\
\hline 2 & Reliability & 11 & 12 & $91.67 \%$ \\
\hline 3 & Convenience & 23 & 24 & $95.83 \%$ \\
\hline 4 & Compatibility & 7 & 8 & $87.50 \%$ \\
\hline 5 & Documentation & 10 & 12 & $83.33 \%$ \\
6 & Audio and Video & 6 & 8 & $75.00 \%$ \\
7 & Visual & 20 & 20 & $100 \%$ \\
\hline \multicolumn{2}{|c|}{ Total } & 88 & 96 & $91.67 \%$ \\
\hline
\end{tabular}

Based on the data portrayed in Table I, the Plagiarism Checker Software media was eligible to be used in learning. The visual aspect got a very valid result which was $100 \%$. The overall result of data analysis of media experts got $91.67 \%$ who had A, categorized as very feasible to use. The visual aspect was also in accordance with what was described by [13]. It was the integration of media where the media must integrate aspects and skills of language to be learned. To attract users, the program must have an artistic and aesthetic appearance.

The product trial was divided into two groups namely small and large. Small group trials were conducted using only a few research subjects. In this experiment, the researcher used a test subject consisting of 10 students of the eleventh class of Software Engineering Skills Competence at State of VHS-2 Singosari Malang who was chosen randomly. The data generated from the aspects that became the indicators in the collection of trial data can be seen in Table II and Figure 4.

TABLE II. SMALL GROUP TEST ANALYSIS

\begin{tabular}{|c|l|l|l|c|}
\hline NO & \multicolumn{1}{|c|}{ Indicators } & \multicolumn{1}{c|}{ Tse } & TSh & \% \\
\hline 1 & Reliability & 110 & 120 & $91.67 \%$ \\
\hline 2 & Convenience & 260 & 280 & $92.86 \%$ \\
\hline 3 & Clarity & 108 & 120 & $90.00 \%$ \\
\hline 4 & Conformity & 149 & 160 & $93.13 \%$ \\
\hline 5 & Documentation & 107 & 120 & $89.17 \%$ \\
\hline 6 & Audio and Video & 65 & 80 & $81.25 \%$ \\
\hline 7 & Visual & 186 & 200 & $93.00 \%$ \\
\hline 8 & Evaluation & 109 & 120 & $90.83 \%$ \\
\hline Total & & 1094 & 1200 & $91.17 \%$ \\
\hline
\end{tabular}

The scores obtained from all the respondents (TSe) in small group trial resulted 1200, while the maximum score of all respondents (TSh) was 1094. If calculated using the prescribed percentage formula, the result of small group trials was (1094: 1200) x 100\% $=91.17 \%$. Based on the data in Table 2, the Plagiarism Checker Software media was considered very feasible and could be used in learning activities. However, the audio and video aspect got $81,25 \%$, of which the result was also relevant to [14] statement of interacting classification in the software media sphere rather than on the hardware system, but rather referring to the characteristics of the user in responding the stimulus 
displayed on the computer screen. Figure 4 illustrates the results of respondents' scores obtained in small group tests in which the scores had been divided according to the indicators used in the data collection process.

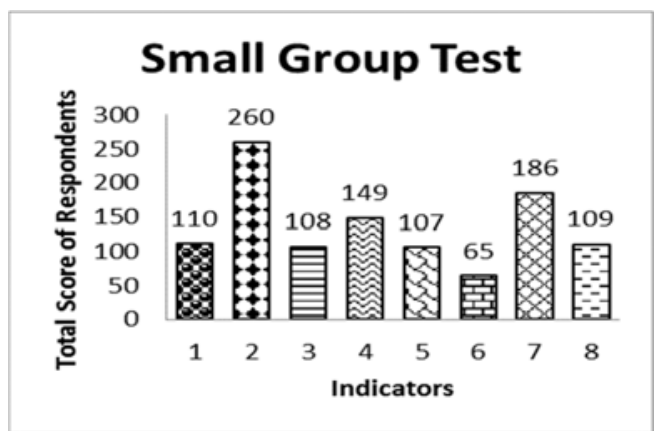

Fig.6. Small Group Test Results

Data of large group test conducted on 36 students of XI grade Software Engineering Skills Competence State of VHS 2 Singosari Malang obtained from all respondents (TSe) from the results of large group trials was 3905. The total score could be seen in Table 3. In Table 3, it also described the acquisition of scores from large group tests that had been adapted to the indicators on the criteria for making a Plagiarism Checker software.

TABLE III. LARGE GROUP TEST ANALYSIS

\begin{tabular}{|l|l|c|c|c|}
\hline NO & \multicolumn{1}{|c|}{ Indicators } & Tse & TSh & $\mathbf{\%}$ \\
\hline 1 & Reliability & 396 & 432 & $91.67 \%$ \\
\hline 2 & Convenience & 946 & 1008 & $93.85 \%$ \\
\hline 3 & Clarity & 390 & 432 & $90.28 \%$ \\
\hline 4 & Conformity & 525 & 576 & $91.15 \%$ \\
\hline 5 & Documentation & 380 & 432 & $87.96 \%$ \\
\hline 6 & Audio and Video & 225 & 288 & $78.13 \%$ \\
\hline 7 & Visual & 658 & 720 & $91.39 \%$ \\
\hline 8 & Evaluation & 385 & 432 & $89.12 \%$ \\
\hline Total & & 3905 & 4320 & $90.39 \%$ \\
\hline
\end{tabular}

While the maximum score of all respondents (TSh) was 4320. If calculated using the predefined percentage formula, the result of large group trials was (3905: 4320) $\times 100 \%=$ $90.39 \%$ Based on the data in Table 3, the highest aspect's score was $93.85 \%$, meaning that this good software was easy to operate for the users, of which was also relevant to [15]. Thus, this software could effectively help students master their operation as expected. The criteria of this Plagiarism Checker software product fell into the very feasible category. This criterion was in accordance with the references from [16] score percentage of total respondents above $85 \%$ can be categorized as very feasible.

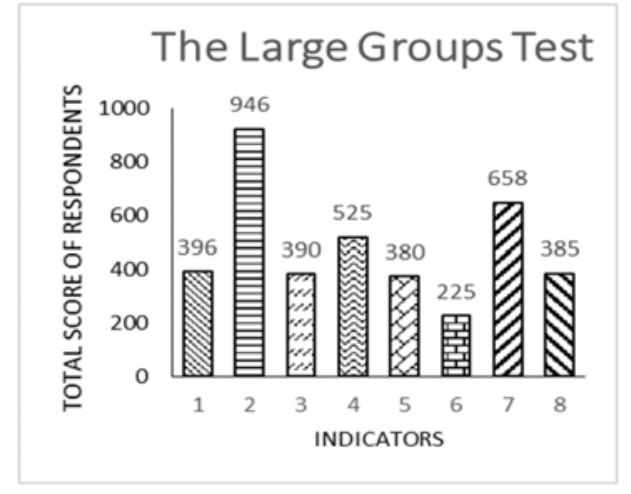

Fig.7. Result of The Large Groups Test

Analysis of the overall results of data collection could be concluded that the test results of the Plagiarism Checker software showed very feasible results with the results of information systems experts $91.67 \%$, small group $91.17 \%$, and large group $90.39 \%$ (see Figure 6). Plagiarism Checker software media could be used in very decent category because the product test result was above $85 \%$. This is certainly in accordance to [16] who states that the learning media products will run effectively and efficiently when tested with various segments. The development of a dynamic, conducive and dialogical media research and development methodology is essential for the development of potential learners. This is because the potential of students will be more aroused when assisted by a number of media or facilities and infrastructure that support the process of interaction that is being implemented. Here, it is expected that there will be an increase in the effectiveness and interaction between lecturers and students so that the learning objectives can be achieved [17].

\section{CONCLUSION}

This study aims to produce Plagiarism Checker software for scientific papers for SMK. The results of this product development can be utilized by all parties in doing a scientific equivalence of scientific papers. In this case, it was implemented on the tasks of students class XI Software Engineering Skills Competence State of VHS 2 Singosari Malang.

After validation of information system experts, and small and large scale test, Plagiarism Checker software can be used in very decent category because the product test result is above $85 \%$.

\section{REFERENCES}

[1] Nachrowi, D. Nachrowi., 2001. “Analisis Sumber Daya Manusia, Otonomi Daerah dan Pengembangan Wilayah dalam Tiga Pilar Pengembangan Wilayah.” Pusat Pengkajian Kebijakan Teknologi Pengembangan Wilayah BPPT. Jakarta.

[2] Gigler, B.S. (2005). "Enacting and Interpreting Technology from Usage to Well-being: Experiences of Indigenous People with ICT. Di dalam Empower Marginal Communities with Information Networking”. Diedit oleh Hakikur Rahman. Hershey, Pen.: Idea Group. 124-164.

[3] _. Inpres Presiden Jokowi Nomor 9 tahun 2016 "tentang Revitalisasi SMK dalam rangka Peningkatan Kualitas dan Daya Saing Sumber Daya Manusia Indonesia". Jakarta. 2016.

[4] . Renstra Universitas Negeri Malang 2015-2019 bahwa dalam bidang sosial, seni, dan budaya, diperlukan penelitian yang mengacu pada peningkatan pembangunan karakter bangsa. Malang. 2015. 
[5] Insley R. "Managing Plagiarism: A Preventative Approach". Volume: 74 issue: 2, page(s): 183-187 Article first published online: April 13, 2011; Issue published: June 1, 2011. https://doi.org/10.1177/1080569911404058

[6] . Permendiknas No. 17 Tahun 2010, Tentang Pencegahan dan Penanggulangan Plagiat di Perguruan Tinggi, Kemendiknas, Jakarta. 2010. $\mathrm{Br}$

[7] Banch, Robert Maribe. "Instructional Design: The ADDIE Approach”. New York: Springer. 2009.

[8] Schleimer S. et all. "Winnowing: local algorithms for document fingerprinting." Proceedings of the 2003 ACM SIGMOD international conference on Management of data. San Diego, California. 2003:76-85.

[9] Elbegbayan, N. "Winnowing, a Document Fingerprinting Algorithm." TDDC03 Projects, Department of Computer Science. Linkoping University. 2005.

[10] Akbar, S. "Instrumen Perangkat Pembelajaran." Bandung: Remaja Rosdakarya. 2014.

[11] Sutjiono, T. "Pendayagunaan Media Pembelajaran." (online). 2005. (http://bpkpenabur.or.id /wp-content/uploads/2015/10/jurnal-No04IV-Juli2005.pdf\#page=82). Diakses 14 November 2017

[12] Prasetyo D., Elmunsyah H., Prihanto D. "Pengembangan Media Pembelajaran Trainer Jaringan LAN untuk Mata Pelajaran Jaringan Dasar pada Paket Keahlian TKJ Kelas X Di SMKN 2 Bojonegoro”. Prosiding-Seminar Nasional Teknik Elektro UIN Sunan Gunung Djati Bandung. 2018.
[13] Ena, O. "Membuat Media Pembelajaran Interaktif dengan Piranti Lunak Presentasi. 2001. (www.ialf.edu/kipbipa/papers/OudaTedaEna.doc). Diakses 14 November 2017

[14] Ali, M. Pengembangan Media Pembelajaran Interaktif Mata Kuliah Medan Elektromaknetik. 2009.. (https://journal.uny.ac.id/index.php/jee/article/view/348). Diakses 14 November 2017

[15] Prastowo, A. "Perbaikan Mutu Pendidikan Melalui Pengembangan Bahan Ajar Mengacu Kurikulum 2013 (online).” 2017. (digilib.uinsuka.ac.id/26794/1/PERBAIKAN\%20MUTU

$\%$ 20PENDIDIKAN\%20MELALUI\%20PENGEMBANGAN\%20BA HAN\%20AJAR\%20MENGACU\%20KURIKULUM\%202013.docx). Diakses 14 November 2017.

[16] Arsyad, A. "Media Pembelajaran." (online). 2011. (https://s3.amazonaws.com/ documents/31182216/jiptiain--umarhadini-8584-5-

[17] baii.pdf?AWSAccessKeyId=AKIAIWOWYYGZ2Y53UL3A\&Expire $\mathrm{s}=1510891764 \&$ Signature $=$ nTQQyIyFUaS7nNn7EGEQaymORKc\% 3D\&response-content-

disposition=inline $\% 3 \mathrm{~B} \% 20$ filename $\% 3$ DMedia pembelajaran.pdf) Diakses 15 November 2017

[18] Elmunsyah, H., "A National Education Policy-Based ICT Model for Indonesian High Schools (VHS)." Global Journal of Engineering Education Vol. 16, No. 3 (Online) 2014.(http://www.wiete.com.au/journals/GJEE/Publish/vol16no3/06Elmunsyah-H.pdf), diakses 26 Juni 2017. 